\title{
Arbor
}

\section{Los orígenes de la Real Botica y sus actuaciones al servicio de los Austrias}

María Esther Alegre Pérez

Arbor CLXIX, 665 (Mayo 2001), 239-265 pp.

\section{Antecedentes de la Real Botica}

La Real Botica, como cualquier otra institución, momento histórico, la propia vida, es un conjunto de sueños y realidades y así debemos contemplarla. En cada una de sus actuaciones, a lo largo de sus cuatrocientos años de existencia, se dejarán sentir connotaciones objetivas y veremos ilusionados proyectos que no se alcanzarán.

La salud y la vida son, por su condición efímera, uno de los valores más preciados para el ser humano. Las personas de la Familia Real, por su circunstancia peculiar, tienen un riesgo añadido, que hace su vida aún más frágil, llevándoles a la necesidad de tener que confiar plenamente en los custodios de su salud: por ello, la elección de estos profesionales debía ser rigurosa; su vigilancia, extrema; y su calidad científica, exquisita.

Las primeras noticias sobre boticarios que atendieron a los Reyes Españoles son escasas y breves en el tiempo. Corresponden a personas al servicio de algunos Monarcas de los diversos Reinos que conformaban la península ibérica e islas adyacentes, quedando constancia documental, en casos muy puntuales, de su denominación como boticario del Rey.

Se tiene información algo más precisa y continuada desde el Reinado de los Reyes Católicos cuando, en fecha 20 de junio de 1475, nombran al boticario aragonés, Maese Jaime Pascual, su boticario personal. Maese Jaime Pascual pertenecía al séquito de Fernando el Católico a quien 
venía sirviendo con anterioridad a su matrimonio. A partir de esta fecha, su nombramiento tuvo carácter vitalicio fijándole una asignación económica. Su actuación profesional no se circunscribió sólo al servicio de las Reales Personas y su séquito, también asumió la organización del servicio farmacéutico en los hospitales de campaña establecidos en las conquistas de Málaga (1487) y de Granada (1492). Esta misión de organizar los hospitales de campañas militares fue una de las funciones de los boticarios del Rey hasta el siglo XIX, en que se creó el cuerpo de Farmacia Militar para cubrir un servicio asumido durante siglos por el personal facultativo de la Real Botica.

$\mathrm{Al}$ fallecer Isabel la Católica, Maese Pascual fue nombrado boticario de la Reina Juana. A partir de aquí, su peripecia vital - personal y profesional- transcurrió al lado de la «Reina Loca», con quien se instaló en Tordesillas, en 1509, sirviéndola hasta 1511, año en el que falleció. Su cargo fue ocupado por el ayudante de Pascual, desde 1501, Bartolomé de Castellón ${ }^{1}$. La estancia de la Reina Juana en Tordesillas (1509-1555), nos pone en contacto, a través de los cuatro boticarios que la sirvieron, con las dos formas habituales de atención farmacéutica a los Reyes Españoles: boticarios Reales y boticarios contratados. Los boticarios Reales, Jaime Pascual (1509-1511), y Bartolomé de Castellón (1511-1519), eran nombrados para el servicio exclusivo de la Reina y su Casa con un sueldo asignado. Los boticarios contratados, Mateo Moreno (1519-1537), y Cristóbal de Génova (1537-1555), eran profesionales establecidos en Tordesillas con botica propia, a los que se contrataba para atender a la Reina y sus criados. Periódicamente debían presentar las recetas dispensadas -obligatoriamente prescritas por médicos del Real Servicio-, por los médicos de Cámara, que comprobaban los datos consignados y la tasación; en caso de acepto se abonaban, englobando este gasto dentro de los ordinarios de despensa ${ }^{2}$.

Por otra parte, tras el fallecimiento de la Emperatriz Isabel en 1539, el Emperador estableció Casas separadas para sus hijos: la Casa del Príncipe Felipe, que ya existía desde 1535; y la Casa de Sus Altezas para sus hijas, Juana y María, incluidas, hasta ese momento en la Casa de su madre la Emperatriz. Las Infantas estarían servidas por un médico, que lo había sido de su madre, un boticario y un barbero, a los que se asignaba un sueldo anual. Este servicio asistiría a las Infantas y sus criados en las distintas ciudades castellanas en las que fijaron su residencia: Ocaña, Alcalá de Henares y Aranda de Duero. En 1548 cesó para la Infanta María, pues al casarse con el Archiduque Maximiliano de Austria, ambos se trasladaron a Valladolid para actuar como gobernadores de España durante la ausencia del Emperador y 
Los orígenes de la Real Botica y sus actuaciones......

del Heredero de la Corona. La atención continuó para la Infanta doña Juana hasta 1552 en que contrajo matrimonio con el Príncipe Heredero de Portugal.

El boticario de la Casa de Sus Altezas tenía asignado un sueldo anual por la atención farmacéutica, y para el abono de las preparaciones que se dispensaban se dispuso que, en cada ciudad donde se fijase la residencia regia, el gobernador de la Casa nombraría supervisor de las cuentas a un boticario privado al que se tomaba juramento de que tasaría las medicinas, bien y fielmente, para no agraviar a Sus Altezas ni al boticario Real ${ }^{3}$.

La Casa del Príncipe don Felipe, en su inicio, tuvo una estructura parecida a la de las Infantas: un médico, un boticario, y un barbero. El boticario, elegido personalmente por el Emperador, fue Jean Jacques d'Arigon - con el tiempo se castellanizó su nombre y apellidos, apareciendo en los documentos como Juan de Arigón-. Permaneció en este servicio durante más de cincuenta años, y en su nombramiento se le encomendaba abastecer de medicamentos al Príncipe, a sus criados, y a dos hospitales: el de Corte, y el de Guarda ${ }^{4}$. La tasación de las medicinas proporcionadas la realizaban dos médicos del Emperador y el médico del Príncipe; además en las ciudades donde residió temporalmente intervinieron en la tasación boticarios del lugar ${ }^{5}$.

Respecto a la organización y protocolo cortesano, la Corte Española se regía por los usos y costumbres del Reino de Castilla, que imponía unos modos muy austeros procedentes de la Corte Visigótica. Cuando el Emperador accedió al trono de España, el ceremonial de la Casa de Castilla se vio desplazado por la etiqueta vigente en la corte de Sajonia - ceremonial de la Casa de Borgoña-, donde el nuevo Rey se había educado. En 1523 y 1528, con motivo de la celebración de Cortes en Valladolid y Madrid, respectivamente, se reivindicó que las Casas Reales se rigieran por las normas de Castilla y estuvieran servidas por castellanos. Se aceptó el último punto, pero no el ceremonial.

Por fin, el 15 de agosto de 1548, tras seis meses de ensayos, se introdujo el ceremonial de la Casa de Borgoña en la Casa del Príncipe. Trece años antes, en 1535, cuando se estableció la primera Casa del Príncipe, el Emperador pidió información sobre los usos y costumbres que se seguían para la formación de un Heredero Real de la Casa de Castilla. Para ello solicitó información a Gonzalo Fernández de Oviedo, que había sido instructor del Infante don Juan, primogénito de los Reyes Católicos; pero cuando en 1547 recibió el informe de Oviedo, el Emperador se había decidido por la etiqueta de Borgoña, 
más rica en magnificencia y ostentación, y a su juicio, más acorde con la importancia de la vasta Corona iba a heredar su hijo ${ }^{6}$.

Con motivo de la grave enfermedad padecida en 1548, en Augsburgo, mandó llamar a su hijo, y ordenó a la Corte Castellana, a través de su Mayordomo Mayor y Capitán General, el Duque de Alba, que pusieran el estado de la Real Casa del Príncipe a la forma y uso de la Casa de Borgoña, como la tenía el Emperador, su padre ${ }^{7}$. Como ya hemos indicado, el 15 de agosto de 1548 se inició el servicio de uso borgoñón. De nuevo las Cortes de Valladolid manifestaron su protesta. El servicio sanitario que acompañó al Príncipe a sus territorios alemanes fue: primer médico, que atendió personalmente al Príncipe; médico de familia, encargado de la asistencia al séquito y servidumbre; y un cirujano. La preparación de medicamentos siguió a cargo de Juan de Arigón, su ayuda Diego de Burgos, y un mozo de oficio. Arigón debía llevar la cuenta detallada de todos los gastos, y para su aceptación tenía que obtener el visto bueno del sumiller de corps y del primer médico, avalado por su firma. Este método se mantuvo durante el viaje que discurrió por Italia, Alemania y Flandes, hasta su regreso a España, en 1551. El Príncipe Felipe volvió a Flandes requerido por su padre, en 1554, pero Juan de Arigón solicitó quedarse en España, y fue su hermano, José de Arigón, el que asumió el servicio hasta el regreso definitivo de Felipe II, en 1559.

\section{Fundación de la Real Botica. Su actividad en el reinado de los Austrias}

Tras la instalación definitiva de la Corte en Madrid, en 1561, la asistencia sanitaria se extendió a todo el personal del Real Servicio y a aquellos particulares o instituciones a los que el Rey concedió derecho a médico y botica. Por este motivo la Casa Real se dividía en cuarteles, y cada cuartel tenía asignados dos médicos de familia $y$ un cirujano ${ }^{8}$. La asistencia farmacéutica se estructuraba en dos ámbitos: la Botica del Rey y la Botica del Común.

La Botica del Rey, instalada en el Alcázar, estaba destinada a dispensar medicamentos a la Familia Real. Los boticarios encargados del servicio eran Juan de Arigón como boticario principal, y Diego de Burgos como Ayuda. La Botica del Común, instalada en la Villa de Madrid, de propiedad privada, era contratada para dispensar medicamentos a los criados Reales. En ese momento Rafael de Arigón fue 
nombrado boticario principal, Bartolomé de Sejo, ayuda, y Pascual López, mozo de oficio.

En los desplazamientos de los Reyes y la Real Familia, la Botica del Rey tenía que constituir la botica del camino, compuesta por cofres acondicionados para transportar simples y compuestos que se necesitarían en el desplazamiento. Esta Botica estaba bajo la responsabilidad de un boticario del Real Servicio.

Aparte de estas boticas, cada vez que se constituía la Casa de los Herederos, era frecuente nombrar un boticario para su atención farmacéutica. Así ocurrió a la llegada de Felipe II, en 1559, de su viaje por Europa, al nombrar a José de Arigón, que le había acompañado en el viaje como boticario de su hijo Carlos, sirviéndole hasta el fallecimiento del Príncipe ${ }^{9}$.

En abril de 1586 la Corte regresó a Madrid tras el viaje a Monzón, y el Rey encargó a Sebastián de Arenzano que se hiciera cargo de la atención en medicinas para los criados de Sus Altezas. Arenzano, que no tenía botica pública en Madrid, se estableció con toda rapidez, y el día primero de agosto de 1586, inició el servicio en su botica contando con un ayuda ${ }^{10}$.

En 1589 se tramitó, a instancias del protomédico, Francisco Valles, una modificación de pesas y medidas de uso en boticas. El origen del sistema ponderal usado en España se fundamentaba en el sistema romano, cuyas adaptaciones corrieron a cargo de Alfonso X el Sabio, y de los Reyes Católicos. Los orígenes de la legislación específica de pesas y medidas farmacéuticas en España no son, actualmente, bien conocidas. Sabemos que, en 1513, Fernando el Católico y su hija Juana, ordenan al platero real, Diego de Ayala, hacer las pesas de botica según las empleadas en Salerno. La diferencia entre el sistema romano y el salernitano consistía en que la base de éste era decimal y la onza equivalía a un peso de nueve dracmas, mientras en el romano era a ocho. Esta norma se ratificó en 1543, por Carlos V, que ordenó al marcador real, Juan de Ayala, hacer las pesas de botica según las de Salerno ${ }^{11}$. Este sistema de pesas perdurará hasta 1591, cuando Felipe II ordene restaurar el sistema ponderal romano.

La pragmática real enfrentó a Valles con los boticarios madrileños y originó el primer roce con los boticarios Reales. Al no modificarse la tarifa de tasación de los medicamentos, los boticarios se consideraron perjudicados en sus intereses económicos y comenzaron a no atender con la debida diligencia a los criados del Real Servicio; las denuncias formuladas por los afectados se sucedieron, y, consecuentemente, se abrió un proceso judicial contra los boticarios Reales. Sebastián de 
Arenzano falleció en 1592, continuando, en el Real Servicio, los hermanos Arigón, pero generaron todo tipo de problemas.

Desde 1590, Felipe II tenía sobre su mesa varias sugerencias del Protomedicato como respuesta a su consulta sobre la actitud adoptada por los boticarios Reales. Una de ellas proponía la instalación de una botica en dependencias palaciegas y la contratación de boticarios con dedicación exclusiva para atención del Real Servicio, con la prohibición de tener botica propia. A principios de 1593 el Rey decidió adoptar ese sistema de atención y se iniciaron los preparativos para implantar la Real Botica. Su ubicación fue la Casa del Tesoro. La nueva botica constaba de dos dependencias: una, para la que se aprovechó la instalación ya existente, destinada a los medicamentos del Rey y su Familia; y otra, la de los oficios, para atender a los criados de Casa y Cámara, cuyas instalaciones comenzaron a prepararse en la primavera de 1593.

En los documentos fundacionales de la Real Botica se insiste en una serie de puntos concernientes al gobierno y administración de la misma: personal cualificado, abastecimiento de drogas y simples, normas de dispensación y su control. La plantilla fundacional consistía en: un boticario mayor o principal, tres ayudas y tres mozos de oficio, todos ellos boticarios examinados; además dos peones se encargaron de las labores de limpieza. Los boticarios debían residir lo más cerca posible de Palacio, incluso, se piensa que el boticario mayor residiera en él. Se estableció un sistema de guardias nocturnas, tanto en la Botica del Rey como en la de oficios - del común-, disponiéndose camas con su ajuar. Nada quedó a la improvisación. La iluminación de las guardias se dispuso de esta forma: en la sala principal de la Botica habría un candil con dos o tres mechas, una de las cuales debía arder toda la noche; en la botica del común tendría que haber cuatro velas, una para la mesa de la pieza principal, otra para la trasbotica, otra para la chimenea, y la cuarta para cuidar el oficio. Diariamente se darían seis velas de sebo en invierno, y cuatro en verano para la guardia nocturna; las velas serían de cera en caso de enfermedad del Rey y se darían todas las necesarias.

La Real Botica dispondría de 100 ducados para el gasto ordinario, y, tanto éste como el extraordinario se librarían por la despensa real. Las compras las haría el Boticario Mayor de acuerdo con el médico de Cámara más antiguo; las hierbas medicinales se traerían de la Casa de Campo, la Huerta de la Priora, y los jardines de Palacio; en tiempo de rosas e hierbas se podría contratar otro peón. En lo concerniente a utensilios e instrumentos, sería el Boticario Mayor el en- 
Los orígenes de la Real Botica y sus actuaciones......

cargado de reponerlos y mantenerlos, los de plata y oro debería encargarlos al Guardajoyas, y los de cobre e hierro, el Bureo ${ }^{12}$.

Cada cuatro meses, los médicos por turnos, harían visitas a cada botica. Las medicinas atrasadas - tres meses- de la Botica del Rey pasarían a la botica del común, y las atrasadas de esta última se eliminaban, descargándose de las cuentas finales. Las medicinas de la botica del común sólo podrían dispensarse por receta debidamente firmada por los correspondientes médicos. También se aprueban las recetas de los cirujanos reales: los cirujanos de familia podían recetar ungüentos, emplastos y aceites; y los cirujanos del Rey también podían recetar purgas y jarabes.

Todos los criados reales, sus esposas e hijos solteros tenían derecho a botica. El Bureo se encargaba de hacer las listas nominales de este personal, entregándolas a médicos y boticarios. La dispensación de medicinas por limosna debía hacerse por receta de médico, avalada por el médico de Cámara más antiguo, y con fe del cura de la parroquia a la que perteneciera el enfermo, para acreditar que vivía de limosna. También el Bureo se encargó de elaborar una lista donde se recogían las medicinas que no se podrían dispensar.

Respecto al sistema de control de la Real Botica, se encargó a un médico de Cámara que, anualmente, revisase el libro de cargo y el libro de menudo. En el libro de cargo se asentarían las medicinas que se comprasen, indicando fecha, cantidad, peso y precio; en el libro de menudo se reflejarían las cosas compradas por menudo indicando la cantidad, así como la razón de la compra, precio y fecha. Con estas instrucciones se inició la andadura de la Real Botica. El 20 de diciembre de 1594 cesaron los servicios de los hermanos Arigón ${ }^{13}$.

Como Boticario Mayor fue nombrado Antonio de Espinar. En un principio sólo se nombraron dos Ayudas: Pablo Ximenez, y Pascual López; y los tres mozos de oficio: Benito de Campelo, Alonso de la Peña, y Martín Pastor. Se indicaba, también, la creación de un laboratorio de destilación, e, incluso, se preveía el nombramiento de Vicenço, a quien ayudaba su hijo, y por lo que ambos tenían ya un salario. Los individuos de la Real Botica ayudarían al destilador en sus ratos libres.

Cuando, entre 1601 y 1606, la Corte madrileña se trasladó a Valladolid, a los criados del Alcázar y Reales Sitios que permanecieron en sus puestos, se les dispuso atención de medico y botica para que no carecieran de ello ${ }^{14}$. En 1606 la Real Botica continuó su actividad en las dependencias de la Casa del Tesoro. En octubre de 1616 falleció Antonio de Espinar, sucediéndole en el cargo Pascual López, que asumió 
el gobierno de la Botica hasta su fallecimiento, en 1628; con este motivo fue nombrado Boticario Mayor, Juan Cazador, que permaneció en el cargo hasta su fallecimiento, en 1641.

El reinado de Felipe IV se caracterizó por el elevado número de reformas económicas y administrativas introducidas. Las primeras reformas, fechadas en 1624, iban encaminadas a reducir el número de criados reales, incrementado notablemente durante el reinado de Felipe III, porque las rentas reales estaban empeñadas y existía una notable falta de hacienda. En las normas que se adoptan, se ordenaba a los médicos reales que recetaran con moderación y cumplieran las normas establecidas. No obstante, a finales de 1630, Juan Cazador elevó un informe al sumiller de corps, exponiendo la necesidad de aumentar el ordinario librado cada mes a la Real Botica pues, el aumento de precio de las materias primas y el incremento en el número de beneficiarios, hacía imposible cubrir los gastos. Consultado el Protomedicato, se emitió un informe favorable indicando: por ser este gasto el mas forçoso y lucido que V. Majestad tiene en su Casa. Aprovechando el buen informe, los individuos de la Real Botica rogaron un incremento de sus sueldos, pues seguían percibiendo los establecidos por Felipe II. El incremento salarial se concedió, para percibirlo, a partir de $1631^{15}$. Sin embargo, la situación económica no experimentó mejoría, los libramientos se retrasaron infinitamente, y, a comienzos de 1638 se debían 8.000 ducados a proveedores.

$\mathrm{Al}$ fallecer Cazador, le sucedió en el cargo Diego de Cortavilla y Sanabria, que fue adelantando de su propia hacienda diversas partidas para no carecer de lo más urgente en la Real Botica. Pese al esfuerzo de Cortavilla, José de Ontiveros, proveedor de la Botica entre 1639 y 1643, y al que se adeudaban 883.000 maravedíes por quiebra de los ordinarios, decidió dejar de abastecer a la Real Botica. En estas circunstancias, Diego de Cortavilla, en diciembre de 1644, envió un escrito al sumiller exponiendo que, en los últimos trece meses, no se había pagado el ordinario de la Real Botica, que ésta carecía ya de algunos géneros necesarios, y que si no faltaban los imprescindibles era por que él había puesto de su hacienda 5.000 reales, pero ya no podía dar al Rey más que su vida.

Con fecha 3 de junio de 1647, apareció una nueva Instrucción del Protomedicato para el buen gobierno de la Real Botica: es la primera vez que se redactaron desde las instrucciones fundacionales. En ella se determinó que la Real Botica debía estar compuesta por un Boticario Mayor, cuatro ayudas, y cuatro mozos de oficio; se especificaron sus cometidos y responsabilidades, y el funcionamiento general de la Real 
Dependencia. Esta Instrucción no aporta ninguna novedad respecto a lo indicado en la fundacional, únicamente, se añade una orden para que el Alcaide de la Casa de Campo, y los jardineros y hortelanos del resto de heredades, que servían a la Real Botica, no dispusieran de rosas ni violetas hasta que ésta no estuviera abastecida, con el fin de evitar comprarlos a drogueros y herbolarios. Además, el aguardiente que se necesitase se traería del destilatorio de Aranjuez como se hacía con las demás aguas medicinales ${ }^{16}$.

En 1650, se jubiló Diego de Cortavilla, fue, sin duda, la figura más relevante, desde el punto de vista científico, profesional y humano, de todos los boticarios de la Real Botica, desde su fundación hasta el siglo XVIII. El Rey le estimaba, y es muy probable que se debiera a su influencia la Real Cédula de 13 de marzo de 1650 —un poco antes de la jubilación de Cortavilla-, firmada por el Rey, declarando la Farmacia Arte Científica. Publicada, inicialmente, para los boticarios madrileños, se hizo extensible a toda España. Se trata de la principal norma legal de la época, según la cual, los farmacéuticos dejaban de ser miembros de los gremios menores artesanales, quedando exentos de ciertos impuestos y servidumbres. A partir de la jubilación de Cortavilla, fue Martín Martínez el nuevo Boticario Mayor, cargo que ejerció hasta su fallecimiento, en 1666.

Los beneficiarios de la Real Botica aumentaban año tras año, $y$, al igual que la asignación se quedaba corta —más el retraso-, los géneros que se facilitaban desde la Real Cámara a la Botica ya no se podían prever; tradicionalmente, con el gasto del año se calculaba el ejercicio del siguiente, pero en esta década nunca se llegó a final de ejercicio. El personal de la Botica también resultaba insuficiente, por ello, en 1661, encontramos seis ayudas.

Coincidiendo con el inicio del reinado de Carlos II, la Real Botica pasó, en 1666, a ser regida por Simón García (1666-1668); tras su fallecimiento le sucedió Juan Bautista Matute (1668-1670); seguidamente vino Jerónimo Izquierdo (1670-1671); y, a su muerte fue nombrado Diego Martínez Pedernoso que ocupó el cargo hasta que, en 1689, es jubilado como consecuencia de una inspección que se gira a la Real Botica en la que se informa sobre su estado de salud - ciego, enfermo y falto de memoria-, pero debido a sus buenos servicios, a su sucesor, Juan de Moya Salazar (1689-1701), se le nombró Boticario Mayor con la condición de seguir con su sueldo de ayuda hasta que falleciera Martínez Pedernoso.

Una de las primeras actuaciones de Martínez Pedernoso fue recibir, con fecha 13 de septiembre de 1671, la nueva Instrucción para la 
Real Botica, que no aporta novedades y sigue manteniendo la obligación del protomédico más antiguo de visitar la Botica una vez por semana - evidentemente no se cumplió pues hubieran reparado antes en su lamentable estado de salud-. Martínez Pedernoso consiguió que, de algunas rentas del Rey - como eran las de la nieve, el aguardiente, y otros-, al momento de su cobranza, se derivase una parte para la Real Botica. No obstante, siguieron los problemas económicos pues, según el memorial que presentó en 1688, el gasto en la Botica era muy elevado debido al gran número de conventos que se atendían, a lo que se daba por limosna, y a la asistencia de la Casa del Rey, de la Reina, y de la Reina Madre.

Los años que gobernó la Botica Moya Salazar, tan cargados de penuria como los anteriores, son los más interesantes de esta etapa. La precaria salud del Monarca hará que, en ella, se crucen las más extremas situaciones científico profesionales $y$, en algunas de ellas, Moya estuvo fuera de lugar.

\section{Boticas temporales excepcionales, para atención de Reales personas en la etapa de los Austrias}

Como hemos indicado, desde el establecimiento de la etiqueta borgoñona en la Corte Española, las Casas Reales eran, fundamentalmente, dos: la Casa del Rey, y la Casa de la Reina, con la consiguiente duplicación de los servicios. Por las investigaciones realizadas hasta este momento, observamos que, sólo las Reinas de origen francés disfrutaron de su propio servicio farmacéutico, independiente del establecido. También se dispuso este servicio para la Reina Viuda, Mariana de Austria, durante su destierro en Toledo; y, para las Infantas, Ana de Austria, hija de Felipe III, y María Teresa de Austria, hija de Felipe IV, con motivo de sus esponsales.

\section{Botica de Isabel de Valois}

Con Isabel de Valois, tercera esposa de Felipe II, apareció el primer servicio farmacéutico, diferente del habitual, destinado a una Reina de España.

Durante su viaje a España desde Francia, venía acompañada por un séquito de más de trescientas personas, entre las que figuraba un médico, un boticario y un barbero o sangrador. Una vez instalada en 
España, Felipe II dispuso unas etiquetas para el gobierno de la Casa de su esposa, integrada, en su mayoría, por el séquito francés que trajo consigo, y de éste, setenta y cinco sirvientes -entre ellos el médico y el boticario- quedaron con Isabel por expreso deseo de su madre la reina Catalina de Medicis. Este séquito aparece citado en la documentación que genera, coloquialmente, como la familia francesa. En el apartado dedicado al personal sanitario aparecen las órdenes destinadas al boticario agrupadas bajo el epígrafe de Boticaria. Están divididas en dos apartados: uno contiene todas sus obligaciones; y el otro detalla los gajes y raciones que les corresponden ${ }^{17}$. Las obligaciones consistían en:

Abastecer medicinas a la Reina, su Casa y criados con mujeres e hijos.

Firma de las recetas por los médicos de Cámara y Familia.

Revisión de las cuentas de medicinas cada fin de mes por el médico real para, una vez aceptadas por éste, entregarse al mayordomo mayor, para que las pase al Bureo.

Libranza de la cuenta de estas medicinas por Furriera.

Formación de una botica del camino entre el boticario y el médico, cada vez que la Reina saliera de jornada

El boticario que asumió el servicio de Isabel de Valois fue Jacques Bobusse, que llegó con ella desde Francia, en 1560, y estuvo a su servicio hasta su fallecimiento, en 1569.

\section{Botica de Ana de Austria}

La Reina Ana de Austria, cuarta esposa de Felipe II, dispuso de servicio farmacéutico propio asignado por su esposo. El nombramiento recayó en José de Arigón, que juró su plaza el 3 de diciembre de 1570, y atendió a la Reina desde esa fecha hasta el fallecimiento de ésta en 1581. Arigón recibió el título de boticario de Su Majestad y Sus Altezas con encargo de abastecer medicamentos a la Reina, sus hijos, así como su Casa y criados. Desde febrero de 1576 contó con la colaboración de Sebastián de Arenzano como ayuda ${ }^{18}$.

Desconocemos en qué momento fue nombrado, pero por las cuentas que presentó a cobro, sabemos que también atendió a los criados de la Reina el boticario Juan de Espinar. Al morir la Reina, este boticario realizó una relación de gastos en medicinas bajo el título: Estas son las medicinas que se han dado a los oficiales de manos de la Casa de la Reina $N .^{a}{ }^{S} .^{a}$ que esté en el cielo desde el principio del año 
1571 hasta el fin de diciembre de 1581. Esta cuenta fue pagada a Espinar en marzo de $1589^{19}$.

\section{Botica de Isabel de Borbón}

Una vez creada la Real Botica, ésta se encargó de servir los medicamentos de ambas Casas Reales y sus respectivos criados. El matrimonio del Príncipe Felipe -más tarde Felipe IV- con la Princesa francesa, Isabel de Borbón, originó la aparición, por primera vez desde la creación de la Real Institución, de lo que podríamos llamar un servicio paralelo al de la Real Botica, conocido como Botica de la Reina. Esta merced especial del Monarca hacia su esposa, sólo nos consta que existiera durante la vida de esta Reina y la de su compatriota, María Luisa de Orleáns, primera esposa de Carlos II.

La Princesa Isabel de Borbón en su viaje de París a Madrid venía asistida por dos farmacéuticos: Jean Gabaux, en calidad de boticario de la Princesa, y Louis de Gras, como ayuda. En principio, la misión de ambos farmacéuticos consistía en abastecer de medicamentos a la Princesa y su séquito mientras durase el traslado, pero no obstante, dicha asistencia se prolongó por espacio de tres años, de 1615 a 1618. Gabaux recibió el título de boticario de la Princesa, y las cuentas que presentó fueron tasadas por un ayuda de la Real Botica ${ }^{20}$. A partir de 1618, Gabaux, ya castellanizạdo como Juan Gabeo, pasó a servir medicinas, exclusivamente, a la Princesa Isabel; las damas y demás criados venidos de Francia se abastecieron de la Real Botica ${ }^{21}$. En 1621, falleció Felipe III, y heredaron el trono su hijo Felipe y su esposa, con lo que Gabeo recibió el título de Boticario Mayor de la Reina. A partir de este momento, la tasación de las medicinas dispensadas por él fue hecha por el Boticario Mayor del Rey. Gabeo, cuyo sueldo se pagaba por la despensa de la Reina, empezó a tener problemas en el cobro de su asignación, razón por la que elevó numerosos memoriales solicitando el abono de los atrasos y rogando que hubiera menos dilación en los abonos anuales ${ }^{22}$. Tal vez por esta circunstancia, el Boticario Mayor de la Reina decidió abrir botica en Madrid. Estamos ante una clara infracción de las normas establecidas para los boticarios del Real Servicio que tenían terminantemente prohibido tener botica. A partir de ese momento sus gajes, que eran 7000 reales anuales, se vieron reducidos a 1200 reales. 
En 1638, Gabeo escribió un memorial manifestando que sus gajes eran de 1200 reales, pero como no se le pagaban, había ido cubriendo el gasto de la Casa de la Reina con su propia hacienda, estando, por ello, embargado y desacreditado. Para obrar en consecuencia, solicitó un informe sobre el proceder con los anteriores boticarios de las Reinas; se le contestó diciendo que, desde 1570 , en que se puso Casa a la Reina Doña Ana, no había existido boticario para ellas ${ }^{23}$.

En 1644, tras fallecer la Reina, Gabeo solicitó pasar a servir a la Infanta Juana en calidad de boticario mayor. Trasladada su petición al Bureo, éste informó de la inconveniencia de tal decisión, pues la Real Botica había abastecido, tradicionalmente, a toda la Real Familia y no se consideraba oportuno innovar nada. A cambio, se le ofreció recibir el título honorífico de Boticario Mayor de Sus Altezas, y abastecer, por cuenta del Rey, a diferentes pobres, particulares y conventos, tal y como lo hacía en vida de la Reina. En 1650, solicitó que se le diera por el Bureo un certificado de lo que le adeudaban. Gabeo falleció el 23 de octubre de $1655^{24}$.

\section{Botica de María Luisa de Orleáns}

La Reina María Luisa de Orleáns, primera esposa de Carlos II, vino a España acompañada por el mismo número y categoría de personal sanitario que, más de medio siglo atrás, había traído Isabel de Borbón: un médico de cámara, un cirujano, y un boticario. El boticario parisino que vino al Servicio Real fue Raymond Verdier. Tras la llegada de la Reina a Madrid, se dispuso que toda su Real Casa, y ella misma, se abastecieran de medicinas de la Real Botica, tal y como se hacía habitualmente. Pero la Reina, tras los meses iniciales, llamó a Verdier para hacerle su Boticario Mayor.

$\mathrm{Al}$ igual que hiciera Juan Gabeo, Verdier estableció botica en Madrid, dispensando en ella las medicinas a la Reina; pero, a la muerte de la Soberana, en 1679, Verdier preparó su marcha a París, en 1680. El Rey le concedió 30 doblones de ayuda de costa para el viaje. No satisfecho con ello, el boticario elevó un memorial al Monarca informándole de los muchos gastos que había tenido en Madrid, desde su entrada en la Corte hasta su regreso a Francia. El rey atendió su memorial y le concedió una cadena de oro de peso cien doblones, y cien doblones más en dinero ${ }^{25}$. 


\section{Botica de la Reina Madre Mariana de Austria}

Durante el destierro de Mariana de Austria, madre de Carlos II, en la ciudad de Toledo, se estableció un nuevo Servicio Farmacéutico para ella, y otro para los criados que la sirvieron en dicha ciudad. Las primeras noticias que aparecen en los documentos de la Real Botica están fechadas en febrero de 1677. El Protomedicato estableció que la asistencia en medicinas para Mariana de Austria corriera a cargo de La Real Botica; desde Madrid se le enviaron todos los medicamentos necesarios, junto con un ayuda de la Real Botica. El abastecimiento de medicinas para la Casa de la Reina Madre se hizo de la botica de Miguel de Bustos, boticario toledano aceptado por el Protomedicato para tales servicios, a instancias de la propia Reina Madre ${ }^{26}$.

Inmediatamente se notificaron estas decisiones al Boticario Mayor del Rey, Diego Martínez Pedernoso, que quedó encargado, también, de establecer la Botica transitoria en Aranjuez, hasta el establecimiento definitivo de la Reina en Toledo ${ }^{27}$. Durante los dos años que duró el destierro, Bustos no sólo se hizo cargo de abastecer a los criados reales, sino también a todos los enfermos, hospitales y conventos que la Reina situó bajo su protección. Estando la Reina en Madrid, en 1683, se encargó a Bustos suministrar las medicinas del convento de Carmelitas Descalzas de Toledo ${ }^{28}$.

Boticas de jornada de las Infantas Ana de Austria, y María Teresa de Austria

Las Infantas Españolas que se desplazaban a otro país para contraer nupcias, iban acompañadas por una Casa Real creada, especialmente, para esa situación. La documentación consultada nos ofrece datos, en este periodo, sobre dos viajes nupciales de Infantas: Ana de Austria, hija de Felipe III, para su matrimonio con Luis XIII de Francia, y María Teresa de Austria, hija de Felipe IV, para su matrimonio con Luis XIV de Francia.

El personal sanitario establecido para esta circunstancia estaba compuesto por, un médico de cámara, un sangrador, un boticario, y un mozo de oficio. Este es el cuadro facultativo que acompañó a Ana de Austria; cuando la Infanta María Teresa partió para Francia, y debido a la reducción de personal del Real Servicio dispuesta por Felipe IV, no figuró en su séquito el mozo de oficio. En ambas situaciones, 
Los orígenes de la Real Botica y sus actuaciones......

el personal farmacéutico encargado del servicio fueron boticarios examinados que ejercían en la Villa de Madrid con botica abierta al público. Hasta el momento desconocemos el criterio de selección utilizado para estos nombramientos, pero sí tenemos constancia de los emolumentos asignados, y que la elección llevaba aneja el nombramiento de los elegidos como personal de la Real Botica. Los individuos que iban con la categoría de boticarios mayores, juraban como ayudas de la Real Botica, y los que iban con categoría de ayuda o mozo de oficio, juraban como mozo de oficio de la Real Botica; por ello, una vez finalizado el servicio, podían hacer uso de su nombramiento.

En 1615, la futura Reina de Francia, Ana de Austria, iba acompañada de las tres categorías de servicio. Su séquito regresó al año siguiente, y los tres boticarios ingresaron en el servicio de la Real Botica ${ }^{29}$. En 1660, la comitiva que acompañó a María Teresa de Austria hasta Francia, tenía, entre sus componentes, dos boticarios cuyas condiciones de contratación eran las mismas. A su regreso, en 1661, el boticario nombrado como boticario mayor falleció al poco tiempo ${ }^{30}$; sin embargo, Antonio de Mora, que fue en calidad de ayuda, no pudo incorporarse como mozo de oficio de la Real Botica por incompatibilidad con su botica particular. Cinco años más tarde vendió su botica en 8778 reales, que estaba situada frente a la Iglesia de Santa Cruz, e ingresó en la Real Botica, donde sirvió hasta su fallecimiento en $1681^{31}$.

\section{Terapéutica en torno a la precaria salud de Carlos II}

Carlos II nació en el Alcázar madrileño el 6 de noviembre de 1661. Fue el último hijo de Felipe IV habido con su segunda esposa. Cuando sucedió a su padre contaba tan solo cuatro años de edad, y actuó como Reina Regente su madre, Mariana de Austria. Carlos II protagonizó dos situaciones insólitas: con él llegó la primera regencia existente desde la unión de las Coronas Castellana y Aragonesa, así como el final de los Austrias en España, al no tener descendencia.

La salud del pequeño Rey fue una constante preocupación para la Corte Española y las chancillerías europeas con pretensiones sobre la Corona Hispánica. Las numerosas referencias a sus enfermedades quedaron reflejadas en la correspondencia de los embajadores franceses y alemanes. Desde su concepción se podían suponer las desgraciadas circunstancias que se darían en él: una trayectoria de matrimonios consanguíneos en sus antepasados, y un padre de avanzada edad casado con una sobrina carnal. Su infancia fue enfermiza, estaba aquejado 
de raquitismo, y no se pudo mantener en pie hasta pasados los cuatro años. A los seis, superada la lactancia y los últimos trastornos gástricos de su infancia, padeció un sarampión que cursó benigno y curó en dos semanas, pero poco después sufrió unas viruelas que pusieron en serio peligro su vida. La infancia de Carlos II fue sobrevivida gracias a los desvelos de su madre y de su haya, la marquesa de los Vélez.

Junto a la medicina tradicional y a la medicina innovadora, se utilizó todo aquello que pareció positivo para restaurar la salud de Carlos II. Entre sus devociones figuraba San Diego de Alcalá, aquel fraile del siglo XV con reputación de milagrero, cuyo cadáver hizo traer Felipe II, en 1562, desde el convento de los franciscanos, a la cabecera de su hijo Carlos. Felipe IV lo haría llevar a palacio durante la enfermedad de su hijo Felipe Próspero, en 1661; el propio Felipe IV estuvo acompañado por el santo en su última enfermedad, en 1665, y lo mismo se hizo con la Reina Mariana de Austria, en 1691. A petición del Rey, San Diego viajó a Palacio en innumerables ocasiones. También se vio acompañado el Rey por el cuerpo de San Isidro y las imágenes de la Virgen de Atocha, y de la Soledad.

El año 1696 sembró de tristeza e inquietud a la Familia Real y su entorno: fallecía la Reina Madre, y Carlos II y su esposa estuvieron gravemente enfermos. El fallecimiento de la Reina Madre ocurría a finales de mayo de un carcinoma de mama. Sólo dos meses antes la Reina comunicó a los médicos reales su situación indicando que, desde hacía mucho tiempo, se había observado una protuberancia en el pecho izquierdo, pero lo había ocultado por la repugnancia que sentía de mostrar su cuerpo a un hombre aunque fuese médico. El examen facultativo reveló que la Reina tenía un tumor de magnitud y tamaño de la cabeza de un recién nacido. El parte médico, fechado a primeros de abril, proponía el empleo de medicamentos atenuantes y evacuantes, esperando que se eliminasen los humores fibrosos. Se buscó algún especialista eminente en Viena, Dusseldorf o Bruselas, y desde la corte imperial, los médicos de Leopoldo I determinaron lo irremediable de la situación. Aún así, se enviaron afamados cirujanos y un no menos afamado médico que llegaron cuando la Reina ya había fallecido.

Por su parte. Carlos II, desde comienzo de año, estaba padeciendo un recrudecimiento de su enfermedad, en primavera presentó fuertes accesos febriles y un fuerte ataque a mediados de septiembre. La gravedad fue tan extrema, que se reunió el Consejo de Estado decidiendo que el Rey firmara un testamento. La ineficacia de los tratamientos habituales y la insistencia de la Reina, decidió a los médicos reales 
Los orígenes de la Real Botica y sus actuaciones......

a hacer un uso de la quina en el tratamiento del enfermo, aunque eran reacios a ello. La insistencia de la Reina se debía a los consejos del médico alemán, Christian Geleen, que había venido a España en la comitiva que acompañaba a Mariana de Neoburgo en calidad de médico personal. Cuando Mariana quedó viuda de Carlos II, instaló su residencia en Bayona (Francia) y allí continuó Geleen a su servicio hasta 1710 , en que falleció ${ }^{32}$.

Una vez administrada la quina, el Monarca experimentó cierta mejoría, pero en octubre se produjo una recaída, que Geleen achacó a una mala aplicación del tratamiento por el desconocimiento de los médicos españoles. A principios de diciembre el Rey estaba libre de tercianas, pero como seguía débil y en cama, se hizo, nuevamente, uso de la quina. La lenta recuperación de los procesos febriles sufridos entre 1696 y 1697, abocaron a los médicos a recomendar una cura ferruginosa y purgas suaves. También se convino en un cambio de aires. La alimentación prescrita se centraba en la carne de víbora para vigorizarle, que se administraba pulverizada a través de pollos cebados con ella. El encargado de suministrar la carne de víbora era el Boticario Mayor, que se vio obligado a solicitar un aumento en su asignación pues, agotadas sus existencias, se veía precisado a comprarlas ${ }^{33}$.

La salud de Carlos II se deterioraba día a día. Desde septiembre de 1700 el Rey entró en un proceso irreversible. Se trajo de Nápoles uno de los mejores médicos, Tommaso Donzelli, y de Sevilla, al paladín del movimiento novator, Juan Muñoz y Peralta. A finales de septiembre, Carlos II no retenía ningún alimento ni medicina, fue sacramentado el día 28, y el día 2 de octubre hizo testamento. El 24 de octubre comenzó una agonía que se prolongó hasta el día de su fallecimiento, 1 de noviembre.

\section{El Real laboratorio químico, consecuencia de la crítica situación en la salud del Rey}

Las etiquetas de 1649 destinadas al Gobierno de la Real Botica, concretamente, en el punto número 11, dicen que sólo el boticario mayor elaborará los medicamentos químicos. En España esos medicamentos eran poco utilizados ya que los médicos fundamentalmente los que dirigían la profesión, no eran partidarios de los mismos. La medicina tradicional era la única oficialmente reconocida en la última década del siglo XVII, y los médicos reales constituían la elite de la profesión, 
procedentes, en su mayoría, de las Universidades castellanas. Los médicos de Cámara eran los candidatos para acceder a los puestos de dirección en el Protomedicato o tribunal que ejercía el control en la selección de los profesionales llamados a ejercer como médicos reales. Esta circunstancia ocasionaba una situación de servidumbre, donde la penetración de ideas que renovaran la terapéutica era prácticamente imposible.

La aparición de los medicamentos químicos en Europa se remonta a la primera mitad del siglo XVI, y está ligada a la figura de Paracelso (1493-1541), médico suizo influido por las creencias alquímicas medievales. Paracelso defendía una terapéutica química basada en arcanos, la quintaesencia, la parte más pura de cualquier sustancia obtenida por destilación. Esta nueva tendencia trajo como consecuencia la aparición de unos nuevos laborantes de la terapéutica, los espagíricos, que utilizaban la parte material, y, por supuesto, técnica de la alquimia en la obtención de medicamentos. España inició la asimilación de las quintaesencias a la terapéutica con los destiladores de Felipe II, y la actuación de Lorenzo Cozar como catedrático de la breve Cátedra de medicamentos químicos de la Universidad de Valencia. Durante todo el siglo XVII, la terapéutica española vivió de espaldas a las nuevas corrientes europeas; tan sólo en el último tercio de siglo, surgió un grupo intelectual que denunció el atraso de la ciencia española: fueron los novatores ${ }^{34}$.

En el cuidado de la precaria salud del Rey, purgas, sangrías, y vomitivos, fueron los remedios habituales. Sólo en los últimos años de su vida, y ante la situación cada vez más alarmante de su salud y del destino de España, se incorporaron nuevas terapias en el entorno Real. En la primavera de 1693 una epidemia de tercianas asoló Madrid. Entre las víctimas de la epidemia se encontraba el duque de Pastrana, sumiller de corps del Monarca. La vida del Rey, también aquejado de tercianas, peligró seriamente durante dieciocho días; y el tratamiento aplicado consistió en purgas drásticas, purgas suaves, sangrías - se le practicaron tres- y repetidos enemas. El inesperado fallecimiento de Pastrana hizo que se nombrara como sustituto temporal al gentilhombre de Cámara más antiguo, el conde de Monterrey, reconocido partidario de las terapéuticas renovadoras y mecenas de Juan de Cabriada, defensor del movimiento novator, que ya, en 1687, había propuesto la creación de un Laboratorio Químico Real como los existentes en las grandes monarquías europeas. Tenemos conocimiento de que el Monarca superó este trance gracias a los cuidados médicos recomendados por Monterrey ${ }^{35}$. 
Tras su recuperación, el Monarca encomendó a su nuevo sumiller, el conde de Benavente, la creación del Real Laboratorio Químico en una estancia aneja a la Real Botica. Esta nueva institución, de marcado carácter renovador, motivó que se congregaran en derredor de Carlos II una serie de afamados médicos de tendencia claramente renovadora, tales como Dionisio de Cardona, que diseñó magistralmente la fundación del Real Laboratorio; Juan de Cabriada, elevado al cargo de médico de cámara; Juan Muñoz y Peralta, y Tomas Donzelli, promovidos, ambos, a médicos de Cámara en los últimos meses de vida de Carlos II. Todos protagonizaron las nuevas terapias a administrar al Rey.

En el entorno Real no se encontraba la persona capacitada para elaborar los nuevos medicamentos del Monarca. Benavente inició sus contactos, y, a través del duque del Infantado, primo del conde de Santisteban en ese momento Virrey de Nápoles, le encargó la búsqueda de un boticario instruido en artes químicas. Consultados los más afamados médicos napolitanos, propusieron a Vito Cataldo, boticario ejerciente en Nápoles, miembro del Colegio de boticarios, examinador y visitador de boticas, e instruido en química y galénica ${ }^{36}$.

Cataldo partió hacia España, el 24 de septiembre de 1693, provisto de productos químicos y recipientes que consideraba necesarios para su ciencia y, sin duda, difíciles de conseguir en España. También le acompañaban dos ayudantes, igualmente instruidos en la química. La llegada a España se produjo el 26 de diciembre de 1693. El 25 de enero de 1694, Benavente notificó al Rey el asiento en la Real Botica de Vito Cataldo como manipulante de la medicina química. Entre sus obligaciones se incluía el encargo de «instruir» a médicos y boticarios de Cámara en la terapia química. En ese momento surgió el primer roce de Cataldo con el Protomedicato. El tribunal argumentó que cualquier médico, cirujano o boticario que pretendiera ejercer la profesión en la Corte, tenía que examinarse ante el Protomedicato ${ }^{37}$, por ello consideraba imprescindible el examen de Cataldo. Benavente se opuso alegando el desconocimiento químico del citado Tribunal. Haciendo uso de su condición de jefe de la Real Cámara, el sumiller impuso al Protomedicato la renuncia a dicho examen a cambio de una disertación de Cataldo ante el Tribunal y los médicos de Cámara. Cataldo juró su cargo el 29 de enero de 1694, en compañía de sus dos ayudantes. Benavente indicó a los médicos y boticarios de Cámara que asistieran, en la medida de lo posible, a las manipulaciones del boticario napolitano, y al Boticario Mayor, Juan de Moya Salazar, que le atendiera en todo lo que necesitara. Nadie cumplió lo indicado por el sumiller. En el verano de 1694, el conde de Benavente tuvo conocimiento de los hechos 
y decidió tomar consejo de alguien entendido, para ello encargó a Dionisio de Cardona la preparación un documento en la forma que considerara conveniente. Cardona envió al sumiller un memorial espléndido, que puede considerarse un auténtico manifiesto novator, en el que propone la creación de un Real Laboratorio Químico, independiente económica y jerárquicamente, del Boticario Mayor, y llevando cuenta detallada de todos los gastos a imagen y semejanza de lo practicado en la Real Botica.

Entre las recomendaciones de Cardona figura:

- Nombramiento de un médico filósofo químico que actuara como Superintendente y Director.

- Custodia bajo llave de los remedios y productos por el propio Manipulador Mayor.

- Obligación de asistir a la instrucción a los oficiales de la Real Botica, cuando lo proponga el Director y Manipulador.

- Publicación de un libro impreso con todos los remedios practicados en el Real Laboratorio, sus descripciones, calidades y dosis.

- Propuesta de venta a precio justo y moderado a los boticarios particulares para no causar mayores gastos a la Real Hacienda.

- Clausura del Laboratorio de Destilación de Aranjuez considerado superfluo, en caso de crearse el Real Laboratorio Químico.

Una vez examinado el memorial de Cardona, el sumiller de corps dispuso las Ordenanzas del Real Laboratorio Químico, que quedaron registradas en los libros de Contaduría y Veeduría con fecha 21 de septiembre de 1694. En ellas se recogen casi todas las recomendaciones de Cardona:

- Independencia económica de Vito Cataldo.

- Nombramiento de directores y superintendentes del laboratorio, a los doctores Andrés Gámez, médico de Cámara, y Dionisio de Cardona.

- Obligación del personal sanitario de recibir lecciones.

- Confección de un libro donde se incluya todo lo realizado en el laboratorio químico.

La ubicación del laboratorio se hizo en dos habitaciones de la Casa del Tesoro que pertenecían a la Real Botica, pero que no estaban siendo utilizadas. Se presupuestaron las obras y Benavente solicitó la libranza del dinero, pero pasados dos años, las obras no se terminaban por falta de provisión económica. Cansados de su inactividad, el 31 de marzo de 1687, los ayudas de Cataldo elevaron un memorial al sumiller pidiendo permiso para regresar a Nápoles; éste se concedió el día 8 de mayo ${ }^{38}$. Un año más tarde, fue Vito Cataldo quien solicitó 
regresar a Nápoles; el Rey le concedió el permiso el día 21 de junio de $1698^{39}$.

En el verano de 1697, el conde de Benavente, recibió un memorial del boticario aragonés, Juan del Bayle, solicitando una plaza en el Laboratorio Químico, dados sus conocimientos de química. El sumiller lo puso en conocimiento del Protomedicato y se solicitaron informaciones sobre Bayle, resultando, sumamente satisfactorias. El Protomedicato le sometió al preceptivo examen, que superó con excelencia, así al menos se desprende del informe que emitió Benavente para que se efectuara el nombramiento: dize el Protomedicato que aviendo parecido en su Audiencia expuesta al examen de Boticario racional y spagírico, Teorico y Practico halla en el ser no solo suficiente, sino es Docto en cada cosa de por si, de suerte que el por si solo puede hazer escuela aparte $^{40}$.

La propuesta que hizo Benavente consistió en que ingresara como ayuda supernumerario de la Real Botica. Cuando Cataldo regresó a Nápoles, Bayle ocupó su plaza de manipulante químico, solicitando que se consignara en los libros de la real Casa su situación. El Real Laboratorio Químico no llegó a funcionar, pero su espíritu siguió vigente a la muerte de Carlos II. La llegada de Luis Riquer como boticario de Felipe V, hizo que este interés quedara en el olvido, hasta que, en 1721, por real orden, fue absorbido por la Real Botica sin llegar a funcionar. Riquer acaparó en su persona los tres cargos que, cuando él llegó, ocupaban personas diferentes: boticario mayor, spagírico mayor, y destilador mayor.

\section{Alquimia al servicio de la salud de Carlos II}

En el verano de 1698 llegó a Madrid, procedente del Reino de Nápoles, Roque García de la Torres de ascendencia valenciana. Este personaje envió al sumiller de corps un memorial de siete folios de extensión, en el que exponía las características y conocimientos que hacían de él la persona adecuada para tratar al Monarca, motivo por el cual se había trasladado desde Nápoles a Madrid. Decía poseer las notas necesarias para fabricar un remedio capaz de prolongar la vida del Rey y hacer posible su sucesión natural.

El sumiller envió este memorial al Protomedicato para que lo examinara y emitiera su opinión sobre el mismo. El Tribunal contestó a Benavente que no podía responder a su pregunta sobre la idoneidad de García de la Torre, porque no pertenecía a ninguna de las profesiones 
que estaban bajo su jurisdicción. Recomendó que fuera Juan del Bayle quien lo examinara pues él era el entendido sobre la materia del manuscrito. El dictamen emitido por Bayle se debatió en sesión conjunta del Protomedicato y los médicos de Cámara. Finalmente, se aceptó la propuesta de Roque García de la Torre. Conscientes de lo que suponía tener un alquimista trabajando para el Rey, se tomaron toda clase de precauciones. Se le instaló en una casa de la calle de Leganitos, frente de la Alcantarilla: ni en la Real Botica, ni en el Laboratorio Químico. Fue asistido por Juan del Bayle. Estaba bajo las órdenes directas del conde de Benavente. Se le pagaba por el Bolsillo Secreto del Rey. La comunicación de Bayle con Benavente era directa.

En la casa de la calle Leganitos se acometieron obras para preparar la residencia de García de la Torre, así como un horno filosófico para su laboratorio. Se le dotó de una importante suma de dinero que él se encargó de dilapidar, pues, aparte de comprar vestuario para su persona, contrató dos criadas y pagó unas deudas que tenía atrasadas. Bayle se instaló en el laboratorio de Leganitos para asistirle en lo que necesitara pero, apenas habían trascurrido seis meses, cuando Bayle transmitió a Benavente su creencia de que García de la Torre era incapaz de elaborar el remedio prometido. Se amonestó al alquimista y se le puso como fecha límite para cumplir su compromiso, el mes de abril de 1699, pero llegado el momento el remedio no estaba elaborado. Desesperado, Bayle regresó a la Casa del Tesoro. Al verse solo, la situación de García de la Torre se volvió crítica, y consciente de su incapacidad, escribió al sumiller pidiendo que se traspasara todo su experimento a Bayle, pues confesó que él entendía mejor. El sumiller no aceptó la propuesta, y, puesto que Roque en su escrito indicaba que solo restaban dos meses de trabajo, le indicó que lo terminara. Así se expresaba Benavente: no doi lugar a eso sino que D. Roque lo trabase esos dos meses y trate de cumplir lo que tiene ofrecido que aquí no lo buscamos se nos vino ofreciendo açerla y si no ubiera puesto contingencias no se le hubiera oido ${ }^{41}$.

El 11 de septiembre de 1699, indicando que dejaba los experimentos por hallarse enfermo: «Haviendo procedido mi Indisposición de haver Travaxado en el asunto que estubo a mi cargo, por recibir los atomos que la materia exalava», Roque promete que, si recupera la salud, se pondrá a trabajar allí donde esté y si consigue la meta, la pondrá al servicio del rey. Un año más tarde falleció Carlos II. Su entorno había intentado todo por salvar su persona y lo que ésta representaba: la continuidad de la dinastía de los Austrias. 


\section{Algunas consideraciones sobre los boticarios mayores}

La plantilla de la Real Botica estaba constituida, como hemos visto, por boticarios examinados, a excepción de las personas contratadas como peones. Compuesta, en un principio, por un boticario jefe que se denominaba boticario mayor, le seguían dos categorías: ayudas y mozos de oficio compuestas por un número variable de individuos, en función de las necesidades de servicio en cada momento. El paso de una categoría a otra se hacía por orden de antigüedad en la escala jerárquica, produciéndose, lo que en los documentos aparece denominado como «ascenso regular». En los momentos de reducción de plantilla no se cubrían vacantes hasta equilibrar el * número de individuos deseado.

Con la llegada de la dinastía Borbón se incluyó una categoría en los boticarios del Real Servicio: la de entretenido, que era la última en consideración jerárquica. A mediados del siglo XVIII se introdujo el acceso a la última plaza de entretenido, vacante tras el preceptivo ascenso regular, y originada por ampliación de plantilla, mediante el sistema de concurso-oposición - cuando hasta ese momento era por designación-, exigiéndose a los aspirantes una serie de condiciones entre las que figura, no tener ningún accidente que haga desgraciada la persona. Aparte de esta consideración, puramente anecdótica, durante los reinado de Carlos III y Carlos IV, entre otras circunstancias, se exigió, además de ser boticario examinado y no tener botica establecida, acreditar pureza de sangre mediante un informe de «buena vida y costumbres», que debía extender el alcalde o el párroco de su localidad; y ser soltero. La condición de célibe se debía a la obligación que tenían los Entretenidos de vivir en la Real Botica, considerándose que el matrimonio supondría un impedimento para cumplir esta obligación.

Durante el reinado de Carlos III, por influencia de su boticario mayor y a instancia del resto de la plantilla, se modificó la denominación de este personal para igualarla a la de los médicos del Real Servicio: las tres categorías de individuos pasaron a denominarse; boticarios de Cámara de primera categoría; boticarios de Cámara de segunda categoría; y, boticarios de Cámara de tercera categoría.

La restauración borbónica en la persona de Fernando VII supuso una drástica reducción en la antigua plantilla, que en el momento de la caída de Carlos IV contaba con ocho individuos en cada categoría. El Rey quería contar con individuos totalmente fieles a su persona. De la antigua plantilla al servicio de su padre, algunos habían fallecidos, 
otros habían abierto botica, y otros fueron considerados afectos al intruso. Con estas premisas la primera plantilla al servicio de Fernando VII la constituyeron, tan solo, tres individuos; a partir de este momento se eliminó, en los concurso-oposición, la obligatoriedad de ser soltero pues, entre otras circunstancias, con el derribo durante el periodo Bonapartista de la Casa del Tesoro, el Servicio de Botica solo disponía de un reducido espacio en el que tan solo estaba prevista la pernocta para cubrir las guardias. Sin embargo se añadió una condición: «fidelidad a la Corona».

El puesto de Boticario Mayor, suponemos, satisfizo a quienes lo ocuparon por la consideración social que llevaba aparejada, pero en modo alguno por la remuneración, porque exigía una gran dedicación, los sueldos eran escasos, y nunca se cobraba en la fecha establecida. El citado retraso afectaba a la asignación económica correspondiente al oficio, y, para evitar desabastecimiento en la Real Botica, los que pudieron, adelantaron de su bolsillo el pago de las provisiones. Esta situación llevó a muchos boticarios mayores a morir endeudados, y en los documentos que hoy se conservan, se acumulan memoriales de sus viudas y herederos reclamando lo que se adeudaba a su esposo o padre, respectivamente.

Todos los boticarios mayores tuvieron una característica común: el celo y la dedicación con que sirvieron a la Corona, así como el interés que mostraron en aprovechar su posición en la Corte para beneficiar a su profesión: la Farmacia. A modo de ejemplo en estos puntos, podemos citar cómo Antonio del Espinar ideó un jarabe destinado al Monarca que denominó, Syrupo Regis Philippi Magistrale, -hecho con agua cocida de anís y sen-, con el que purgó a Felipe II, y resultó tan efectivo, que alcanzó gran fama en todo el Reino de Castilla. También podemos destacar a Diego Cortavilla y Sanabria, que compaginó su ejercicio de Boticario Mayor de Felipe IV con su dedicación al estudio de la botánica. En un pequeño huerto que poseía en Madrid, cultivó plantas raras, herborizó la sierra del Paular, y escribió dos obras dedicadas al estudio de las culebras. En lo concerniente a la profesión, en época de Diego Cortavilla se obtuvo la consideración de la Farmacia como, "Arte Científica».

Durante el periodo Borbón, fueron tres boticarios, fundamentalmente, los que obtuvieron mayores el acierto de convencer a los Reyes, Carlos III y Carlos IV, para que tomaran una serie de resoluciones decisivas para la profesión, que marcaron la Historia de la Farmacia Española. Estos boticarios fueron: José Martínez Toledano, Juan Díaz, y Francisco Rivillo. A ellos se debe el inicio del autogobierno de la 
Farmacia con la escisión del Protomedicato en tres Audiencias: Medicina, Cirugía, y Farmacia - Protofarmacéuticato, presidido por el boticario mayor-, y la creación, en los albores del siglo XIX, de la Junta Superior Gubernativa de Farmacia que suponía la independencia absoluta de la Farmacia. La consecuencia de esto fue la promulgación de las primeras Ordenanzas de Farmacia en las que se disponía la creación de los Colegios de Farmacia para impartir enseñanzas específicas a esta facultad y otorgar los pertinentes títulos académicos que posibilitaran el ejercicio profesional.

$\mathrm{Su}$ calidad científica queda patente, no solo por la labor que desempeñaron, también a través de los informes que emitieron sobre identificación de plantas y otros productos medicinales; una buena parte de ellos sobre producciones de las colonias ultramarinas.

\section{Notas}

1 A.G.S., CSR, leg. 16.

2 REY BUENO, M. ${ }^{a}$ M. (1999): Tradición y modernidad. La asistencia farmacéutica en la Corte española en los siglos XVI y XVII. Tesis doctoral. Facultad de Farmacia. Universidad Complutense de Madrid.

3 A.G.S., CSR., leg. 64.

4 Ut. Supra.

5 A.G.S., CSR., leg. 61.

6 Fernández de Oviedo, G. (1870): Libro de la Cámara real del Príncipe Don Juan e Oficios de Su Casa e servicio ordinario. Madrid. Sociedad de Bibliófilos Españoles.

7 CALVETE DE EstRelLa, J. C. (1552): El felicísimo viaje del muy alto y muy poderoso príncipe Don Felipe, hijo del Emperador Don Carlos Quinto, desde España a sus tierras de la Baxa Alemania. Amberes. En Rey Bueno, 1999.

8 A.G.P.., S. a., leg. 690.

9 A.G.S., CSR., leg. 280.

10 A.G.P, E. P, $125 / 10$.

11 REY Bueno. (1999).

12 A.G.P., S. S., leg. 429.

13 A.G.P., S. A., leg. 468.

14 A.G.P., C. R., tomos X y XI.

15 A.G.P., B. A., leg. 429 .

16 A.G.P., S. A., leg. 645.

17 A.G.S., CR, J.O.B., leg. 383.

18 A.G.P., E. P., 1341/8.

19 A.G.P., E. P., 125/10.

20 A.G.P., cuentas leg. 6657.

21 A.G.P., E. P., $382 / 7$.

22 Loc. CT a 20. 


\section{María Esther Alegre Pérez}

23 A.G.P., S. A., leg. 429.

24 A.G.P., E. P., 382/9.

25 A.G.P., E. P., 1087/44.

26 A.G.P., E. P., 2607/17.

27 A.G.P., S. A., leg. 429

28 A.G.P., E. P. $1087 / 44$.

29 A.G.P., E. P., 705/17.

30 A.G.P., E. P., 641/13 A.G.P., S.A., leg.626.

31 A.G.P., E. P., 705/17.

32 A.G.P., E. P., 430/32.

33 A.G.P., S. A., leg. 429, leg. 645.

34 LÓPEZ PIÑERO, J. Ma. (1969): La Instrucción de la ciencia moderna. Barcelona.

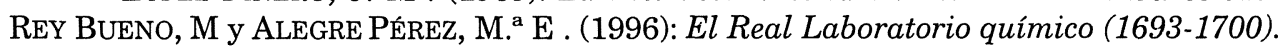
Dynamis 16.

35 Duque de Maura. (1954): Vida y reinado de Carlos II. Madrid.

36 A.G.P., S. A., leg. 429.

37 Muñoz Miguel, E. (1751): Recopilación de leyes, Pragmáticas, Reales Decretos $y$ acuerdos de Real protomedicato. Valencia.
38 A.G.P., E. P., 2613/18.
39 A.G.P., E. P., 91/6.
40 A.G.P., Leg. 429.
41 Ut supra. 
Los orígenes de la Real Botica y sus actuaciones......

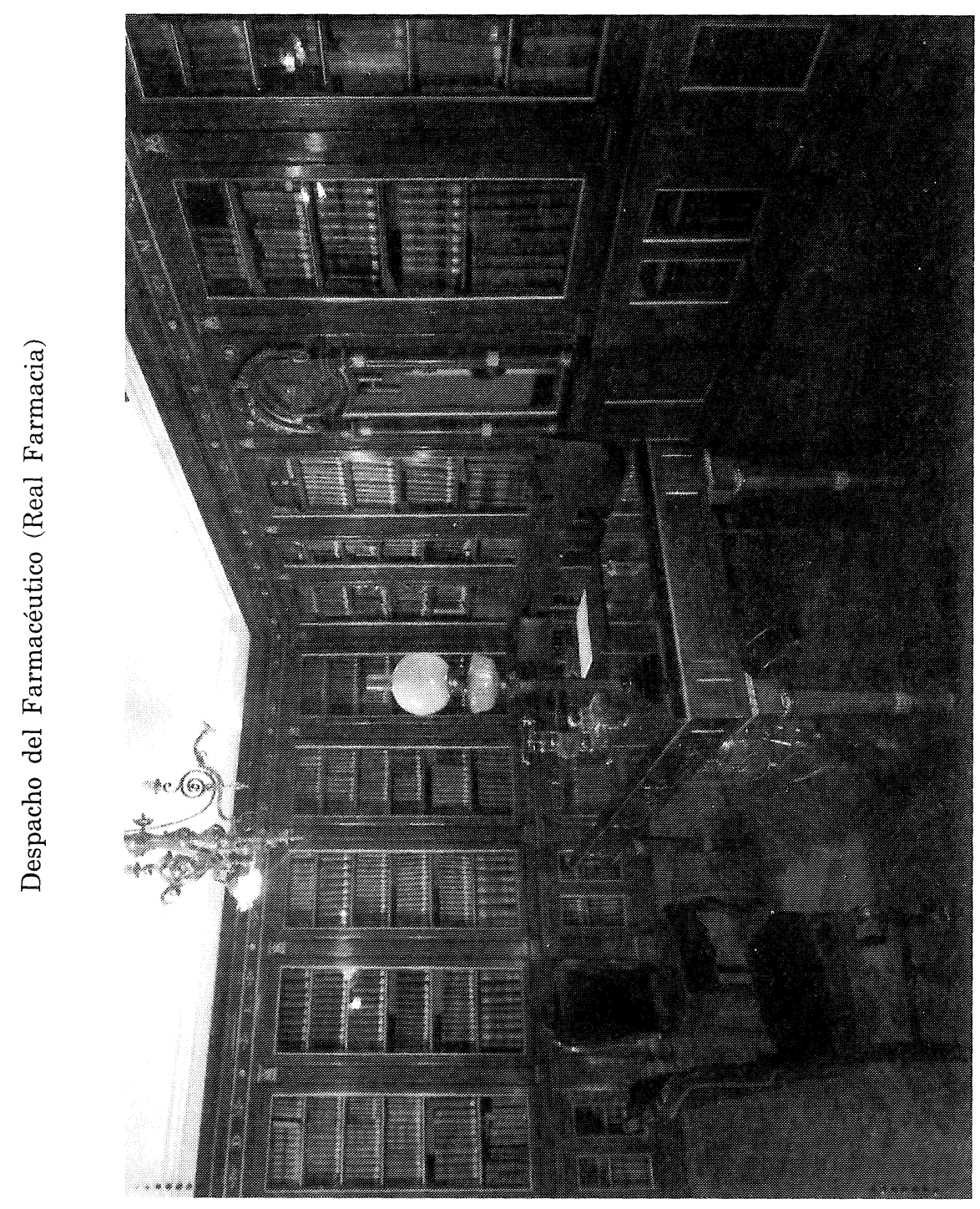

